Tomasz Nastulczyk

Research Centre of Estreicher Family Polish Bibliography

Jagiellonian University, Kraków, Polska

tomasz.nastulczyk@uj.edu.pl

ORCID 0000-0002-1596-2363

\title{
What did remain of the worn out editions? The collections of the local and foreign libraries as the base for research of the Polish popular books of the second half of the $19^{\text {th }}$ century (a case study of selected religious and didactic publications)
}

\begin{abstract}
The paper offers an insight into the poor state of preservation of the Polish popular publications of the second half of the $19^{\text {th }}$ century, based on systematic queries for the new edition of the Estreicher family Bibliografia Polska XIX stulecia (Polish Bibliography of the $19^{\text {th }}$ century). The queries revealed that many of the editions in question are now completely lost, and quite often the only one or two survived copies can be found either abroad or in small local libraries/museums. The discussed examples include several popular books by the Roman Catholic bishop, Szymon Marcin Kozłowski; the commonly used primer for country children (Elementarz dla chłopców wiejskich for boys and Upominek dla dziewczat wiejskich for girls); and the religious publications of Blessed Father Honorat OMFCap (Florentyn Wacław Koźmiński). Problems with the preservation of popular books from cultural borderlands are illustrated by the case of the Lutheran catechism published by Rev. Karol Kotschy for the local Silesian evangelical community in Ustroń. Finally, a few examples of the $19^{\text {th }}$-century Polish-American mass publications are discussed.
\end{abstract}

Key words: $19^{\text {th }}$ century - popular publications - state of preservation of books - foreign libraries - local libraries.

„Z Badań nad Książką i Księgozbiorami Historycznymi” - Udział zagranicznych recenzentów w ocenie publikacji; Stworzenie anglojęzycznej wersji wydawniczej publikacji; Digitalizacja tomów archiwalnych rocznika w celu zapewnienia otwartego dostępu do nich przez Internet oraz wdrożenie i utrzymanie cyfrowej platformy redakcyjnej - zadanie finansowane w ramach umowy $\mathrm{nr}$ 653/P-DUN/2019 ze środków Ministra Nauki i Szkolnictwa Wyższego przeznaczonych na działalność upowszechniającą naukę. 
Everyday work on development of the new edition of the Estreicher family Bibliografia Polska XIX stulecia ${ }^{1}$ (Polish Bibliography of the $19^{\text {th }}$ century), in particular, systematic inquiries in large and small domestic and foreign libraries, enable practical insight into preservation status of Polish books published after the year 1800. Although a lot of them can be found in main Polish academic book collections, however, it happens systematically that localization of at least one copy requires wide, intensive inquiries.

These situations repeat quite often in regard to publications of a specific type. By no means it applies to prints perceived as rare and valuable in their time, as they have been cautiously stored in academic libraries, knowing their value. Neither these are albums, atlases or maps - these, although usually stored in a few copies, have been carefully protected, collected and described by the units specialized in protection of so-called special collections, which can always be consulted or asked for help in inquiries ${ }^{2}$. Systematic difficulties concerning the residual degree of conservation of the copies appear where they were deemed not to be expected, as they refer to any type of high-volume popular books (fair, cheap, religious, didactic, etc.), i.e. mass publishing production of the $19^{\text {th }}$ century ${ }^{3}$.

Reasons for that are quite simple. Poor quality of production (in particular bad quality of paper) did not assure adequate books' durability, and their utilitarian character (as objects passed from one person to another) favored fast wearing of editions. An important factor was also a lack of systematic, institutional protection. Wide dissemination of a given edition in a given historical moment did not favor thinking about the current collection and preservation of copies for the needs of further generations. Common disregard for selected types of literature from outside high culture addressed to not-elitist (folk) recipients, has also been significant until recently. Finally, important academic libraries have been treating such printings as valueless for many decades - with all consequences ${ }^{4}$.

1 The source base for this article includes materials gathered for the needs of volumes 19 and 20 of K. Estreicher, Bibliografia Polska XIX stulecia, new edition. T. 19, by the team managed by W. Walecki, ed. T. Nastulczyk, Kraków 2015; idem, Bibliografia Polska XIX stulecia, new edition. Vol. 20, by the team managed by W. Walecki, ed. T. Nastulczyk, Kraków 2016.

2 Only to mention, that during works on the entry concerning geographical atlases of Blasius Kozenn, a kind help of Waldemark Spallek from the Laboratory of History of Cartography, Department of Geoinformatics and Cartography, University of Wrocław was crucial. Finding copies of different editions of this atlas was possible (among others) thanks to support of the Staff of the Department of Cartographic Collections, National Library of Poland. See: K. Estreicher, op. cit., vol. 20, pp. 30-34; W. Spallek, Polskie szkolne atlasy geograficzne 1771-2012, Wrocław 2018, p. 42.

3 Comprehensive state of research on the Polish popular book of the $19^{\text {th }}$ century (together with detailed bibliographic data) is presented in the article: A. Gruca, Badania nad ksiażka i jej rodzajami w Polsce po II wojnie światowej, „Roczniki Biblioteczne” 2016, vol. 60, pp. 173-179 (point 4).

4 See for example: J. Dunin, Papierowy bandyta. Ksiązka kramarska i brukowa w Polsce, Łódź 
However, publications of that kind turn out to be now the more important research material. They document not only the development of popular readership and popular culture of the book but moreover - the birth of the modern mass society, in which along with literacy, moral attitudes, personal models and worldviews were disseminated. A clear testimony of this process are social, religious and didactic publications, directed to mass readers, and aimed at their complete development in the spirit of certain values. This group consists of catechisms, primers, religious and moral readings, economic and hygiene guides, anti-alcohol warnings, popular prayer books or moralizing the lives of the saints. Often (but not always) these are books either "for the folks" or "for the youth", joining several forms and functions. Reconstruction of the models promoted in that time, often still alive in the cultural consciousness of the Polish society, requires reliable fixing in bibliographic data, in particular in regard to number and frequency of editions, engagement of particular publishing centers, or content modification in the following editions.

However, it often turns out that the only trace of the once interesting and popular book is a record (made almost up-to-date) in the first edition of Bibliografia Polska XIX stulecia. Intensive inquiries reveal singular, often very damaged copies in local public libraries, in smaller university libraries or in church collections all over the country. Searched publications can also sometimes be found in foreign book collections, stored there as foreign language curiosities or former legal deposit $t^{5}$. Therefore analyzing and describing "worn out editions" require source inquires much wider than only in the largest Polish academic centers.

Characteristic cases of such publications are writings of the Mogilev archbishop Szymon Marcin Kozłowski. His texts were reprinted almost year by year in different cities of the Russian Empire in the second half of the $19^{\text {th }}$ century. As found in Polski stownik biograficzny (Polish biographical dictionary): "na jego książkach uczył się zasad religii katolickiej ogół młodzieży w cesarstwie rosyjskim aż do XX w. Na szerzenie wiedzy religijnej K[ozłowski] kładł duży nacisk, biednym rozdawano jego podręczniki za darmo"“6 ("the youth, in general, learned the rules of the Catholic religion in the Russian Empire until the 20th century on his books. K[ozłowski] put an emphasis on dissemination of religious knowledge, the poor received his textbooks for free"). Meanwhile

1974, pp. 20-21; P. Grochowski, Straszna zbrodnia rodzonej matki. Polskie pieśni nowiniarskie na przelomie XIX i XX wieku, Torun 2010, pp. 18-19; A. Gruca, op. cit., pp. 173-174.

I discuss it more broadly in introduction to the article: T. Nastulczyk, Dlugie trwanie tradycji staropolskiej, czyli «Kotwica (w) ostatniej toni», [in:] Nihil sine litteris. Scripta in honorem Professoris Venceslai Walecki, ed. T. Nastulczyk, S. Siess-Krzyszkowski, Kraków 2017, pp. 529-531.

6 See: M. Żywczyński, Kozłowski Szymon Marcin, [in:] PSB. Vol. 15: Kozłowska Zofia - Kubacki Stanisław, Wrocław-Warszawa-Kraków 1970, pp. 31-32. 
preservation status of particular editions revealed to be quite poor. Many of them were completely lost, and their existence is attested only by the brief contemporary mentions or a significant gap in editions numbering - when it was consequently applied. As for the most popular religious printings by archbishop Kozłowski, "new editions" of which were published fast and not very carefully, as the publishers thought only about answering the permanent need of the readers, even these indirect testimonies have not been preserved. However, the author's biography and territories of his preaching activity (the Mogilev Archdiocese) suggested that additional materials can be reached by inquiries in the collections abroad, in particular in Vilnius and Saint Petersburg.

Intensive searches realized by the team of Bibliografia Polska XIX stulecia (in particular Beata Opoka) gave very good results: in foreign catalogues and repositories, many editions preserved - as it seems - in unique copies only were found (and de visu described) ${ }^{7}$. Just mention that in the Wróblewski Library of the Lithuanian Academy of Sciences (Lietuvos mokslų akademijos Vrublevskių biblioteka-LMAVB) in Vilnius is preserved the only one known copy of the anonymous, Zhytomyr edition of Nabożeństwo kościelne na niedziele $i$ święta catego roku (Church service for Sundays and holidays throughout the year, 1892). Saint Petersburg edition of this book (1895) is owned only by the National Library of Lithuania (Lietuvos nacionalinè Martyno Mažvydo biblioteka-LNB). The same was thought about the Zhytomyr edition of 1891 published in two parts until its copies were found in the Library of the Warsaw Province of the Friars Minor Capuchin in Zakroczym. We have also found "lacking", i.e. not preserved anywhere else, copies of two-piece Historyja święta dla uzytku mtodzieży (Holy history for the youth use) $-8^{\text {th }}$ edition of part two (1879) and $10^{\text {th }}$ edition of part one (1884) in the LNB. The $3^{\text {rd }}$ edition of part two (1860) is preserved only in Vilnius collections; moreover, the copy of part one (1860) is also in the Dominicans' collection in Kraków, and its reissue from 1864 (also described as the " ${ }^{\text {rd }}$ edition") - in the University Library in Olsztyn.

Different publishing variants have also been found in local Polish libraries, documenting almost permanent work of the printers - for example in the Diocese Seminar Library in Legnica the copy of the $7^{\text {th }}$ edition of part one was found, with edition date moved by a year (1878 instead of 1877) in regard of three other known copies, preserved in the Jagiellonian Library (Biblioteka Jagiellońska-BJ), LMAVB and LNB.

Moreover, two unique (and quite worn out) copies of two editions of the very popular prayer book Stużba Boża (Divine service, 1865, 1881) were found in the latter, and the unique copy confirming the following edition of this work (1893) is being stored in the Library of the Russian Academy of Sciences in

$7 \quad$ K. Estreicher, op. cit., vol. 20, pp. 80-96. 
Saint Petersburg (Biblioteka Rossijskoj Akademii Nauk - RAN). The University Library in Białystok stores the only one known copy of the $1^{\text {st }}$ edition of Elementarz polski (Polish primer, 1859), the unique copy of the Zhytomyr edition of Rok kościelny, czyli wyktad obrzędów kościelnych (Christian year, i.e. a lecture of church rites) of 1893, and the other copy (next to the Vilnius one) of the Rok kościelny edition from 1890 - again it is revealed that academic centers established after the World War II have started gathering collections of very valuable historical books.

However, the most interesting settlements were done concerning Historyja święta i katechizm dla dzieci (A holy history and catechism for children). Its $5^{\text {th }}$ and $6^{\text {th }}$ editions $(1869,1873)$ are known only from the unique copies in the LNB. The $20^{\text {th }}$ edition (1896) was found in the BAN in Saint Petersburg. The inquiry of foreign sources revealed existence of a Lithuanian remake (Istorija szwenta Seno Istatimo. Iszimta isz knigu viskupo Kazlauskio), reprinted in quite extraordinary circumstances: ban introduced after the January Uprising (1863-1864) for publishing books in Lithuanian language with Latin alphabet caused that such publications were secretly printed in Eastern Prussia, with fake publishing address and retroactively dated. Later they were smuggled into Lithuania and disseminated as publications from before a ban. Thanks to access to digitized catalogues and the ePaveldas digital repository, we easily located four illegal editions of this text, allegedly published in Vilnius by Józef Zawadzki in 1859 and 1864, and actually printed in Tilsit, in the years 18871904. Copies of these editions are preserved in collections of most important Vilnius libraries and - again - in the BAN in Saint Petersburg.

A few unknown editions and publishing variants were discovered of the popular folk primer for reading and writing education - Elementarz dla chtopców wiejskich (A primer for rural boys) and the parallel Upominek dla dziewcząt wiejskich (A gift for rural girls) by Aleksander Albert Krajewski and, respectively, Jan Kanty Gregorowicz and Seweryna Duchińska (primo voto Pruszakowa $)^{8}$. These are classic books "for the youth and for the folks", where primer content is completed with prayers, Krótki zbiór katechizmu wedtug Kościoła Świętego Rzymsko-Katolickiego (A short catechism of the Holy Roman Catholic Church) and secular quasi-catechisms Prawdy gospodarskie przez starych gospodarzy na pytania $i$ odpowiedzi ułożone (Farm truths by old farmers in questions and answers arranged, for boys) or Prawdy domowe $i$ gospodarskie dla kobiet $i$ dziewczat wiejskich (Household and farm truths for rural women and girls).

8 Unclear problem of authorship of both these versions is definitely explained in (overlooked until recently) obituary by T. Korzon, Aleksander Krajewski (A. A. K.), „Biblioteka Warszawska” 1903, vol. 1, pp. 330-333, offering profound presentation of the text and detailed range of works of each of its authors. See: K. Estreicher, op. cit., vol. 20, pp. 198-201. 
Analysis of the books, discovery of unknown editions and clarification of bibliographic data confirmed that we are dealing with an utter bestseller. Each version had over a dozen of editions. Estreicher's notes indicate that Elementarz was sold at least in 130000 copies, and particular editions of Upominek amounted to 6000 or 10000 copies. However, not many copies in different domestic and foreign libraries are available today, which proves complete worn out of the editions.

The second edition of Elementarz (1860) is known from the copy in the Polish Library in Paris. Another copy of this edition (a publishing variant, probably?) is registere in the LMAVB catalogue, however, the renovation of library storehouses and therefore long-term exclusion of parts of the collection prevented us from verifying this information. Although both primers had been published for years by the Gebethner \& Wolff publishing house in Warsaw, thanks to the inquiry in the Lithuanian collections we also discovered the unnumbered edition of Elementarz with publishing address in Vilnius - from 1861 (copies in the LMAVB and the University Library in Vilnius - Vilniaus universiteto biblioteka). There is no information about a publisher, only that the main storage is located in the Maurycy Orgelbrand's bookstore. Assuredly, it was to confuse Russian authorities. Unnumbered is also a shortened edition of 1862, preserved in the Library of the Adam Mickiewicz University Library (Biblioteka Uniwersytecka Uniwersytetu Adama Mickiewicza - BU UAM) in Poznan - this time it is most likely a variant to be distributed in the Grand Duchy of Poznań. The $4^{\text {th }}$ edition (1863), stored in the Kraków collection of the Library of the Polish Academy of Learning and the Polish Academy of Sciences (Biblioteka Naukowa Polskiej Akademii Umiejętności i Polskiej Akademii Nauk - PAU/PAN) is available also only in the Polish Library in Paris. The $8^{\text {th }}$ edition (1876) was described referring to the copy from the BAN in SaintPetersburg. Another copy is registered in the card catalogue of the University of Warsaw Library (Biblioteka Uniwersytetu Warszawskiego - BUW), however, it has not been found. Edition no. 15 (1892) is stored in both these libraries, but the copy in Saint Petersburg has no publishing date on the title page. Copies of editions no. 12 (1885), 14 (1889) and a "new one" (1895) are available in the BUW only. The $7^{\text {th }}$ edition (1874) remains unknown: currently, we have only a record from that time, in the first edition of Bibliografia Polska. Editions no. 10 and 13 are not attested at all. Moreover, the analysis of Lithuanian academic literature reveals information about Elementarz translation into Lithuanian by Mikołaj Akielewicz (Mikalojus Akelaitis), printed in 1860 in 5000 copies, none of which has been preserved ${ }^{9}$.

9 Nacionalinès bibliografijos duomenu bankas, [online] http://nbdb.libis.lt/simpleSearch. do? marcFullType=full\&BI001=C1R0000048603 [retrieved on 21.10.2018]; http://nbdb.libis.lt/sim- 
As regards Upominek, the preservation status of the copies is a little bit different. We have not found so many atypical variants dispersed in foreign libraries, therefore collections of larger Polish academic libraries turned out to be sufficient. Again, the unique role of the BUW collection should be underlined, where unique copies of editions no. 5 (1865), 10 (1876), 11 (1878) and 16 (1889) are preserved. Also, there are stored two copies of "the new edition" of 1893, which after de visu verification turned out to be variants with the changed title page. One of these variants was also found in the BAN in Saint Petersburg, and the other in Poznan collections (copies in the BU UAM and in the Library of the Poznan Society of Friends of Sciences). The $4^{\text {th }}$ edition of Upominek (1863) is saved only in one copy in the PAU/PAN collection in Kraków, and the $13^{\text {th }}(1883)$ - again in the collection of the BU UAM in Poznań. The $6^{\text {th }}$ edition (1869) is confirmed only by Estreicher record, and editions no. 3, 7, 8, 9, 14 and 15 are still missing.

Similar is the situation of popular printings promoting new patterns of Christian devotion. Particularly interesting examples are publications by Blessed Father Honorat OMFCap (Florentyn Wacław Koźmiński) ${ }^{10}$, promoting the cult of the Most Holy Face of Jesus in the second half of the $19^{\text {th }}$ century. Most of his popular works are quite well preserved, as they were carefully collected in either academic or church libraries, in particular by his confreres (a large collection is now available in the Library of the Warsaw Province of the Order of Friars Minor Capuchin in Zakroczym). However, very specific exceptions are noted here. The first edition of Nabożeństwo wynagradzajace (Réparatrice) do Oblicza Pańskiego (Rewarding service to the Lord's Face, 1890) is preserved in one copy only (in the library of Dominicans in Kraków), and the first edition of Miesiac Najświętszego Oblicza Pańskiego (A month of the Holy Lord's Face, approx. 1899) is known only due to its introduction to the reissue (1899, cover date 1900):

W przeciągu niespełna dwóch miesięcy, pierwsze wydanie niniejszej książeczki Miesiąc Najświętszego Oblicza Pańskiego, zostało zupełnie wyczerpane. Czyniąc zadosyć licznym żądaniom, podajemy ponownie do druku tę malutką pracę naszą, pomnażając ją i uzupełniając, dodatkiem po każdej medytacyi jakiegoś krótkiego opisu, z życia św. Weroniki, z historyi czci Najświętszego Oblicza, z objawień siostry Maryi od św. Piotra [Perrine Éluère], z życia P. Dupont [Léon Papin Dupont] lub z cudów zdziałanych w jego Oratoryum tak za jego życia, jak po jego świątobliwej śmierci ${ }^{11}$.

pleSearch.do?marcFullType=full\&BI001=C1R0000048609 [retrieved on 21.10.2018].

10 K. Estreicher, op. cit., vol. 20, pp. 139-145. Due to beatification of father Honorat in 1988, many years after finishing works on the $\mathrm{H}$ letter entries (ibidem, vol. 10, ed. K. Estreicher jun., Kraków 1972), we had to withdraw from the general Estreicher rule of placing entries concerning Christian saints and blessed under their first names.

11 [F.W. Koźmiński - o. Honorat OFMCap], Przedmowa, [in:] [idem], Miesiąc Najświętszego 
(Within less than two months the first edition of this book Miesiąc Najświętszego Oblicza Pańskiego was sold completely. Satisfying demands of the many, we publish again this small our work, multiplying it and completing with a short description after each edition, concerning life of St Veronica, history of the Holy Face of Jesus adoration, revelations of sister Maria of St Peter [Perrine Éluère], life of P. Dupont [Léon Papin Dupont] or miracles made in his Oratory either during or after his holy life).

Meanwhile, two following editions of Nabożeństwo $(1893,1900)$ are much better preserved: the $2^{\text {nd }}$ edition is stored in Zakroczym and in the Jagiellonian Library, and the $3^{\text {rd }}$ one - in the BUW, in the Ossolineum in Wrocław, and again in Zakroczym. Moreover, new, expanded edition of Miesiac Najświętszego Oblicza Pańskiego is preserved in at least 5 libraries (BJ, BUW, Zakroczym, Library of the Catholic University of Lublin and the Library of the Higher Clerical Seminary of the Salesian Society in Lad). As one can imagine, the first editions, of a smaller number of copies probably, were sold immediately ("within less than two months") and certainly because of that, they were missed by librarians. Copies could have been collected by libraries just after satisfying social needs, therefore they were obviously following editions.

One can also notice that with no engagement of communities caring for documentation of father Honorat activities, we would have much fewer preserved copies. Lack of such interest probably contributed to the situation (overlooking or oblivion) of the anonymous book summarising preaching of this charismatic clergyman. Nabożeństwo wynagradzające i Cześć Przenajśw. Oblicza Pańskiego streszczone wedtug Nowego Daru Jezusa przez O. Honorata Kapucyna przez *** (Rewarding service and worship to the Holy Lord's Face, summarized according to the New Gift of Jesus by Father Honorat Capuchin by ***, 1893) is preserved only in the Library of Metropolitan Chapter in Przemyśl - not in institutional academic, seminar or monastic collections, but in the one for private usage of the canons ${ }^{12}$.

The other topic is popular regional printings, in particular, those from cultural borderland. In such cases, problems of poor preservation status of books for mass readers are joined with local social, ethnic, religious or political circumstances. Classic is the example of religious and didactic works for the Polish people in Silesia.

During works on the new edition of Bibliografia Polska XIX stulecia we had to face this problem, constructing the entry concerning writings of Rev. Karol Kotschy, a Polish-German Lutheran clergyman active for many years in the evangelical community in Ustron. For the needs of his preaching work, he developed Kateizm [sic!] Doktora Marcina Luthera (Doctor Martin Luther's

Oblicza Pańskiego, [2nd extended edition], Warszawa 1899 (cover date: 1900), p. 7.

12 I kindly thank Father Prelate Józef Bar for offering me access to this copy. 
Cateism [sic!]), the first edition of which was published in Moravian Brno in $1833^{13}$.

This printing, besides Polish versions of texts by German reformer (catechism, prayers and moral guidance titled Tablica domowa, A household table), consists also of texts by Rev. Kotschy himself, among others materials for learn reading in Polish (together with multiplication table), a sermon against drunkenness (Gorskie kapki ale zdrowe, Bitter drops, but healthy), occasional religious songs, and even two translations of works of the German poet Friedrich Gottlieb Klopstock. Due to specific circulation of Silesian writings, the only one copy of Kateizm preserved in Poland can be found in the Cieszyn Library, two other in the Moravian Library (Moravská zemská knihovna) in Brno and in the Research Library (Vědecká knihovna) in Olomouc, the fourth in the Austrian National Library (Österreichische Nationalbibliothek) in Wien - probably the former legal deposit.

The real problem seemed to be the $2^{\text {nd }}$ edition, at the beginning known only from the Estreicher's record as Katechizm dla szkót ewangelickich (Catechism for Lutheran schools) and dated "184.", what meant publication in the 40s of the $19^{\text {th }}$ century. This time a copy was found neither in Cieszyn nor in Czech or Austrian libraries. However, this did not discourage us in further searches, with a positive final result. Fortunately, we found a relation from the meeting for the commemoration of Rev. Kotschy activity, organized by the Polish Evangelical Society in the Evangelical Parish in Ustron. This relation was illustrated and included a photo of 2 pages of Kateizm, with expanded primer part - a clear indication that this comes from the $2^{\text {nd }}$ edition ${ }^{14}$. Severely worn out, but enormously valuable copy was finally localized in the collection of the Ustron Museum (see: Photo) ${ }^{15}$. The $2^{\text {nd }}$ edition of Rev. Kotschy's Kateizm was published in Brno in 1843.

A related theme worth mentioning here is the book heritage of the Polish diaspora abroad, in particular, mass publications in Polish language printed in the second half of the $19^{\text {th }}$ century in the United States. In the local context, determined in that time mostly by "folk" economic emigration, the role of publications of that kind was particularly important. Popular books, due to their egalitarian character, enabled mass readers to maintain a relation with Polish culture and language, influencing dominantly development and perpetuation of the national identity of the emigrants, regardless of their education level.

13 K. Estreicher, op. cit., vol. 19, pp. 148-149.

14 M. Pilch, Spotkanie PTEw - Ks. Karol Kotschy, [online] http://www.ustron.luteranie.pl/spotkanie-ptew-ks-karol-kotschy.html [retrieved on 21.10.2018].

15 I kindly thank Rev. Dariusz Lerch from the Evangelical Parish in Ustroń, and Michał Pilch from the Society of Friends of Ustron for their support in localising the copy. I also thank the Museum of Ustron for offering me access to digital materials and authorisation of publishing the title page. 
At the same time, the commercial character of many publishing undertakings provided the Polish book institutions with finances necessary for their further functioning in difficult social and economic American contexts (including also funding for publishing works perceived as more serious and demanding).

Photo. Kateizm Doktora Marcina Luthera by Rev. K. Kotschy - the unique copy of the $2^{\text {nd }}$ edition (1843). Courtesy of the Ustron Museum

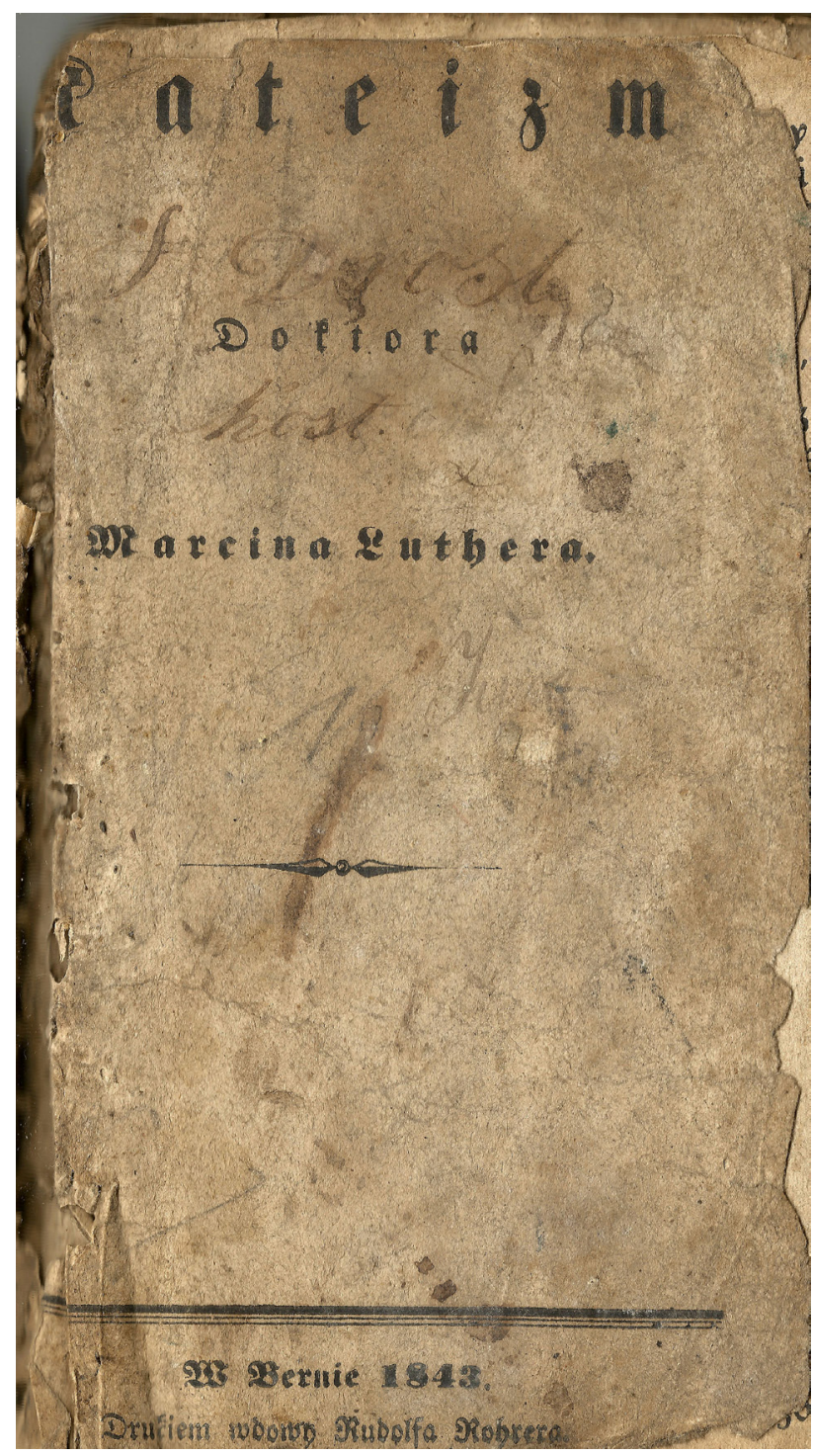


In the repertoire of Polish-American publishers of that time examples of the simplest (para)literary fair or devotional production, as well as the literature of a slightly higher intellectual ambition can be found, directed to the mass reader and often related to a given didactic and formation program. A brief review of materials from current volumes of the new edition of Bibliografia polska XIX stulecia reveals for example that Władysław Dyniewicz in his publishing house in Chicago published simultaneously a fair version of Historyja o siedmiu medrcach (The story of the seven wise men) by the 16th century writer Jan of Koszyczki $(1879,1880,1891)^{16}$, a popular Żywot św. Wojciecha (Saint Adalbert's life) by father Hilary Koszutski $(1881,1882,1890)^{17}$, a romantic, didactic and patriotic novel Zemsta, czyli wymierzenie sprawiedliwości przez Polkę kochająca catem sercem ojczyznę i jej bohaterów (Revenge, or justice by a Polish woman loving homeland and her heroes with all her heart) by Stefania Kossowska vel Ida Teibels $(1878,1880,1888)^{18}$, and the tragedy for Polish schools Sobieski pod Wiedniem (Sobieski at Vienna) by father Kandyd Kozłowski $(1883,1895)^{19}$.

Obviously popular non-commercial printings of the Polish diaspora extending beyond this scheme should also be mentioned here. An interesting example of such publication, directly for mass reader, is a catechism-like Ekonomia polityczna (Political economy) by the Polish philosopher, sociologist and naturalist Władysław Mieczysław Kozłowski (known also as Katechizm ekonomii spotecznej, Catechism of social economy, approx. 1897). The unique copy of this book was found in the Poznan Society of Friends of Sciences Library, donated by the author's family. It has neither a cover nor a title page, but only a protective sheet with a handwritten note:

W. M. Kozłowski. Ekonomia polityczna. Pragnąc ułatwić moim słuchaczom - gronu pracowników ręcznych polaków [sic!] w Buffalo NY - przyswojenie głównych zasad swych wykładów, spisałem je w formie katechizmu, który sam składałem dla „Siły” [polonijne czasopismo socjalistyczne - T.N.] i sam odbijałem na nożnej prasie. K[ozłowski]. 1896-820. (W. M. Kozłowski. Ekonomia polityczna. I wanted to facilitate my listeners - a group of workers, the poles [sic!] in Buffalo NY - internalisation of main rules of my lectures, I wrote them in a form of catechism, and personally typed and printed for "Siła" (Strength) [socialist journal of the Polish diaspora - T.N.] on a foot press. K[ozłowski]. 1896-8.)

The preservation status of the whole mentioned publishing production seems to be very bad $^{21}$. Popular books of the Polish diaspora were under the same

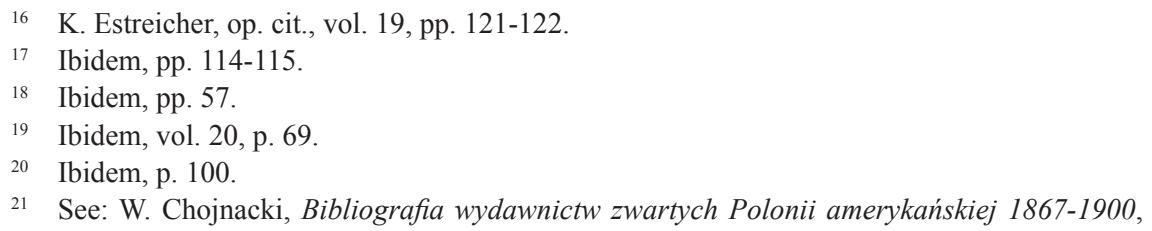


circumstances as analogous domestic publications (poor quality of production, fast worn out and insufficient institutional protection), but at a much larger scale. One has to refer also to the context of the Polish diaspora in America in the $19^{\text {th }}$ century as a socially excluded religious and ethnic minority. A network of secular and ecclesiastical institutions, able to guarantee the endurance of historical book collections, was much weaker in the US than in Poland, due to obvious reasons. It predominantly consisted of social organizations of Polish diaspora and Polish Catholic institutions scattered throughout the territory of the US (parishes, seminars, friaries). They required first of all usable libraries, focusing more on cultural and educational activity than conscious documentation of current publishing life.

Moreover, these institutions had not always maintained continuity of their functioning, which conduced dispersion, or even destruction of the collections. The problem is still valid: tracing now Wojciech Chojnacki, who in his fundamental Bibliografia wydawnictw zwartych Polonii amerykańskiej 1867-1900 (Bibliography of monographs of the Polish diaspora in America 1867-1900) of the year 1991 documented valuable content of many important libraries of the Polish diaspora, one cannot found numerous copies registered that time, because organizations which shared their collections with Chojnacki, in the following years changed their profile, name, structure, function, and personal composition and their libraries were closed and dispersed ${ }^{22}$. This kind of institutional fluidity has hindered proper identification of the collections being sought and localization of their current curator. Contact information in guides and Internet websites turn out to be outdated, mails receive no answer, and historical collection, even if finally found, often turns out to be completely disorganized. Specific of the Polish-American social and religious institutions is also their lower level of administrative formalization, as a result of which old books can wander among them in not exactly controlled nor documented way ${ }^{23}$.

Against this background an extremely valuable work should be appreciated, being realized reliably and systematically for many years by the Polish

\footnotetext{
Warszawa-Kraków 1991, pp. 17-22 (chapter Stan zachowania poloników amerykańskich z XIX w.).

22 See: B. Bieńkowska, Wstęp, [in:] Wspótczesne księozbiory polskie za granica. Informator. Vol. 1: Polskie i polonijne księgozbiory instytucji, B. Bieńkowska, E. Maruszak, J. Puchalski, Warszawa 2009, pp. 13-14.

23 Examples of such practices can be found in the guide Wspótczesne księgozbiory polskie..., p. 398: „W 2003 r. [Polska Czytelnia w Buffalo] liczyła ok. 8000 polskich książek i czasopism. Ok. 2005. do Bibl. przyjechał «furgonetką» ks. R. Nir, który zabrał do Centralnego Archiwum Polonii w Orchard Lake [...] wybrane przez siebie książki. Reszta pozostaje nie rozpoznana i nie uporządkowana”. (,In 2003 [the Polish Reading Room in Buffalo] amounted to approx. 8000 Polish books and journals. Approximately in 2005 father R. Nir came to the library with «a van», and took the books he selected to the Central Archives of American Polonia in Orchard Lake [...]. The rest is still unexplored and disorganised").
} 
Museum of America for the protection of the printed heritage of the Polish diaspora in the US. With no difficulty, we found in its collection either one of the two known copies of the mentioned above Chicago edition of Zemsta ... by S. Kossowska of $1878^{24}$, or the unique copy of the Polish diaspora edition of the comedy Stryj przyjechat (Uncle arrived) by Władysław Koziebrodzki (1900) ${ }^{25}$.

Fortunately, many of the mass books of the Polish diaspora have been preserved in domestic libraries. Therefore we found copies of Chicago editions of a few popular dramas by father K. Kozłowski: Powstanie Polaków, czyli Rok 1863 (The Poles' Uprising, i.e. the year 1863, 1886) in the Nicolaus Copernicus University Library in Torun, and Św. Mikolaj (Saint Nicholas, 1885) in the Ossolineum in Wrocław ${ }^{26}$. The aforementioned edition of Historyja o siedmiu mędrcach of 1891, not registered in existing bibliographies, was found in a single copy in the University of Wrocław Library. However, these are usually only unique, accidental findings. Any synthetic description on their basis is hardly possible. Bibliographic fundament for systematic studies on Polish-American publishing production of the $19^{\text {th }}$ century must be based on materials considering collections of the Polish diaspora libraries (reliably verified de visu). A valuable work of Chojnacki should be a guide here, but not - as it is now a bibliographic ersatz of unavailable, although (let's hope) not yet lost books.

Studying the history of "worn out editions", one should remember about hidden treasures of local libraries (either secular or ecclesiastical ones), regard also museum collections, as well as put particular attention to the contents of book collections outside Poland (of either large academic libraries or traditional collections of the Polish diaspora). Only due to such work, often possible only thanks to the kind help of curators of a given collection, we can get the right perspective on the history of the Polish mass book of the $19^{\text {th }}$ century, treated by time and history so unkind.

Translated by Matgorzata Kisilowska

\section{References}

Chojnacki W., Bibliografia wydawnictw zwartych Polonii amerykańskiej 1867-1900, Warszawa-Kraków 1991.

Dunin J., Papierowy bandyta. Książka kramarska i brukowa w Polsce, Łódź 1974.

Estreicher K., Bibliografia Polska XIX stulecia, new edition. T. 10, ed. K. Estreicher (jun.), Kraków 1972.

24 According to W. Chojnacki the other copy was to be in the collection of the aforementioned Polish Reading Room in Buffalo. See: W. Chojnacki, op. cit., p. 230, point 1323.

25 K. Estreicher, op. cit., vol. 20, p. 43.

26 Ibidem, p. 69. 
Estreicher K., Bibliografia Polska XIX stulecia, new edition. T. 19, by the team managed by W. Walecki, ed. T. Nastulczyk, Kraków 2015.

Estreicher K., Bibliografia Polska XIX stulecia, new edition. T. 20, by the team managed by W. Walecki, ed. T. Nastulczyk, Kraków 2016.

Grochowski P., Straszna zbrodnia rodzonej matki. Polskie pieśni nowiniarskie na przełomie XIX i XX wieku, Toruń 2010.

Gruca A., Badania nad książka i jej rodzajami w Polsce po II wojnie światowej, „Roczniki Biblioteczne" 2016, vol. 60, pp. 165-185.

Korzon T., Aleksander Krajewski (A. A. K.), „Biblioteka Warszawska” 1903, vol. 1, pp. 319-349.

[Koźmiński F.W. - o. Honorat OFMCap], Miesiąc Najświętszego Oblicza Pańskiego, [2 $2^{\text {nd }}$ expanded edition], Warszawa 1899 (cover date: 1900).

Nacionalinès bibliografijos duomenu bankas, [online] http://nbdb.libis.lt/ [retrieved on 21.10.2018].

Nastulczyk T., Dlugie trwanie tradycji staropolskiej, czyli «Kotwica (w) ostatniej toni», [in:] Nihil sine litteris. Scripta in honorem Professoris Venceslai Walecki, ed. T. Nastulczyk, S. Siess-Krzyszkowski, Kraków 2017, pp. 529-544.

Pilch M., Spotkanie PTEw - Ks. Karol Kotschy, [online] http://www.ustron.luteranie.pl/ spotkanie-ptew-ks-karol-kotschy.html [retrieved on 21.10.2018].

Spallek W., Polskie szkolne atlasy geograficzne 1771-2012, Wrocław 2018.

Współczesne księgozbiory polskie za granica. Informator. T. 1: Polskie i polonijne księgozbiory instytucji, B. Bieńkowska, E. Maruszak, J. Puchalski, Warszawa 2009.

Żywczyński M., Kozłowski Szymon Marcin, [in:] Polski słownik biograficzny. Vol. 15: Kozłowska Zofia - Kubacki Stanisław, Wrocław-Warszawa-Kraków 1970, pp. 31-32. 